\title{
1 Linear scaling of precipitation-driven soil erosion in laboratory 2 flumes
}

3 S. Jomaa $^{\text {a, }}{ }^{*}$, D.A. Barry ${ }^{\text {b }}$, M. Rode ${ }^{\text {a }}$, G.C. Sander ${ }^{\text {c }}$, J.-Y. Parlange ${ }^{d}$

$4 \quad{ }^{\mathrm{a}}$ Department of Aquatic Ecosystem Analysis and Management, Helmholtz Centre for Environmental

5 Research - UFZ, Brueckstrasse 3a, 39114 Magdeburg, Germany. Ph. +49 (391) 810-9135; +49 (391)

6 810-9650; Fax. +49 (391) 810-9111. E-mail addresses: seifeddine.jomaa@ufz.de,

7 michael.rode@ufz.de

8 b Laboratoire de technologie écologique (ECOL), Institut d'ingénierie de l'environnement (IIE),

9 Faculté de l'environnement naturel, architectural et construit (ENAC), Station 2, Ecole Polytechnique

10 Fédérale de Lausanne (EPFL), 1015 Lausanne, Switzerland. Ph. +41 (21) 693-5576; Fax. +41 (21)

11 693-8035. E-mail address: andrew.barry@epfl.ch

$12{ }^{\mathrm{c}}$ Department of Civil and Building Engineering, Loughborough University, Loughborough LE11 3TU

13 United Kingdom. Ph. +44 (1509) 223-777; Fax. +44 (1509) 223-981. E-mail address:

14 g.sander@lboro.ac.uk

$15{ }^{\mathrm{d}}$ Department of Biological and Environmental Engineering, Cornell University, Ithaca, New York

16 14853-5701 USA. Ph. +1 (607) 255-2476; Fax. +1 (607) 255-4080. E-mail address:

17 jp58@cornell.edu 
The proportionality between raindrop-driven soil erosion delivery and area of soil exposed to raindrops under a uniform precipitation rate was investigated in terms of individual size classes using laboratory flume experiments. In particular, we examined the dependence of soil erosion on the area exposed to raindrop detachment. Twelve experiments were performed on the same laboratory flume, filled with the same soil. The experiments entailed different (constant) precipitation rates (28 and $74 \mathrm{~mm} \mathrm{~h}^{-1}, 2-5 \mathrm{~h}$ duration) and various fractions of exposed surface (20, 30, and 40\%, created using rock fragment cover). In addition, different initial soil conditions (dry hand-cultivated, wet sealed-compacted and dry compacted) were considered. The discharge rates and the sediment concentrations of seven individual size classes $(<2,2-20,20-50,50-100,100-315,315-1000$ and $>1000 \mu \mathrm{m})$ were measured at the flume exit. Results showed that the proportionality of soil erosion to the area exposed appears to always hold at steady state independently of the initial conditions and rainfall intensity. Across all experiments the data indicate that this proportionality holds approximately during entire erosive events and for all individual size classes. However, the proportionality for short times is less clear for the larger size classes as the data show that for these classes the erosion was sensitive to the soil's antecedent conditions and further influenced by additional factors such as surface cohesion, surface compaction and soil moisture content. 


\section{Introduction}

The factors influencing raindrop-driven soil erosion can be divided into two main categories; rainfall characteristics (precipitation rate, duration, raindrop size) and soil properties (moisture content, topsoil compaction, surface roughness) (Butzen et al., 2014; Liu et al., 2014; Ries et al., 2014; Saedi et al., 2016). A good understanding of these factors and of their interactions is needed for predictions of sediment concentrations (Bryan, 2000; de Vente et al., 2013; Jomaa, 2012; Keesstra et al., 2016).

At the catchment scale, several studies focused on obtaining a unique relationship between flow characteristics and sediment concentrations (de Vente et al., 2013; Harmel et al., 2006; Nearing et al., 2007; Pierson et al., 2001). These studies consistently reported a non-unique relationship between sediment concentrations and runoff response. Generally speaking, sediment delivery is found to increase with the flow volume from a given basin area (Kim, 2013). Keesstra et al. (2016) reported that additional factors such as agricultural land management (e.g., tillage, herbicide and vegetation coverage) further affect the soil erosion delivery. For instance, it was found, experimentally, that straw mulch reduces soil erosion and runoff generation significantly (Cerdà et al., 2016; Prosdocimi et al., 2016). Kim (2013) listed and detailed the possible parameters influencing this relationship, i.e., rainfall characteristics, land use and cover, surface roughness, antecedent soil conditions, conservation management practices and the development of surface water connectivity as well as the steepness and length of slopes. Nearing et al. (2007) showed experimentally that event-based soil erosion delivery can differ considerably for the same hydrological response at the catchment outlet due to interactions amongst factors including soil degradation, loss of soil organic matter, or change in vegetation cover. Recently, de Vente et al. (2013) reviewed and evaluated 14 soil erosion models used in over 700 catchments. They found that prediction of sediment 
concentration strongly depends on the spatial and temporal scales considered. They concluded that, at the catchment scale, none of the models captures all soil erosion processes and fulfils all modelling objectives. For instance, in large catchments, nonlinear regression models were found to represent more accurately the sediment concentrations. Factorial scoring models with identification of dominant soil erosion processes were more reliable for medium-sized catchments (de Vente et al., 2005; Haregeweyn et al., 2005). Process-based models, however, were found to better represent soil erosion delivery only when the modelled processes are dominant in the investigated study area (de Vente et al., 2013; Haregeweyn and Yohannes, 2003; Jetten et al., 1999). Thus, de Vente et al. (2013) concluded that further integration of observations and different model concepts is needed to obtain better soil erosion predictions. This work is a step in that direction. We consider the transferability of measured soil erosion data under laboratory-controlled conditions, i.e., if, at a given site, erosion measurements are available under a given set of conditions, can those results be scaled when the conditions (e.g., precipitation rate or area exposed) change?

At the field scale, the factors that influence soil erosion cannot be imposed. However, this is not the case for laboratory flume experiments. Therefore, numerous studies have highlighted the importance of the use of simulated rainfall experiments to better understand soil erosion processes and to predict sediment delivery (e.g., Iserloh et al., 2013; Lassu et al., 2015; Martínez-Murillo et al., 2012). Jomaa et al. (2012a) investigated the relationship between the temporal evolution of total eroded mass from a laboratory flume and the area exposed to raindrop detachment. In that study, the temporal soil erosion delivery from a rock fragment-protected flume (flume 2) was estimated by multiplying the time-varying eroded mass from the bare soil flume (flume 1) by the fraction of exposed soil to raindrops in flume 2. The proportionality between soil erosion and the area exposed to raindrops worked surprisingly well for the duration of the experiment, and was able to estimate reliably the 
temporal behaviour in the total sediment concentration leaving flume 2 . The most accurate estimates of the measured flume 2 concentrations were obtained when conditions settled down to steady state.

In this study, we consider the applicability of these findings in terms of the behaviour of the individual size classes. As with the total eroded mass discussed above, the measured sediment concentrations of the individual size classes from flume 2 were also estimated from flume 1 data based on the exposed area of soil in flume 2. Specifically, we (i) investigate the proportionality between surface area exposed and the eroded sediment concentration for individual size classes through time, and (ii) assess how much these relationships are controlled by the antecedent soil conditions.

\section{Material and Methods}

\subsection{Experiments}

Previously published data from the EPFL erosion flume and an additional experiment were utilised, all of which were for the same loamy agricultural soil. To compare the effect of different exposed surface areas, the 6-m $\times 2$-m EPFL flume was separated into two identical 6-m $\times 1$-m flumes, identified as flume 1 and 2. Experiments for flume 1 always started with a bare soil surface, while flume 2 experiments considered different levels of surface rock fragment coverage (Fig. 1); otherwise the experimental conditions (surface roughness, soil cohesion and soil initial moisture) for each flume were identical. For all experiments, the rock fragments were placed on the top surface (not embedded in the soil). The design of experiments, the rainfall simulator characteristics and the soil property as well as its preparation procedure were described previously (Jomaa et al., 2010; Jomaa et al., 2012b; Tromp-van Meerveld et al., 2008), so only key features are discussed here. The flume was filled to a depth of $0.32 \mathrm{~m}$ with an agricultural loamy soil from Sullens, Switzerland, and 
underlain by $0.10 \mathrm{~m}$ of coarse gravel facilitating the drainage. The flume slope can be adjusted in the range $0-30 \%$ using a hydraulic piston. Water from Lake Geneva was applied to the flume by 10 Veejet 80150 nozzles located on two parallel oscillating bars (each contains five Veejet nozzles), $3 \mathrm{~m}$ above the soil surface. The rainfall intensity can be adjusted by changing the oscillation frequency of the sprinklers. Over the course of each rainfall event, water and sediment samples were collected in individual bottles at the exit of each flume. Continuous sampling occurred at the beginning of the runoff generation to capture the early soil erosion peak. Afterwards, the sampling period increased due to less rapid changes in sediment concentration as the system tended toward steady-state.

In this study, we analyse results from 12 experiments using two rainfall intensities (28 and $74 \mathrm{~mm} \mathrm{~h}^{-1}$ ) and three rock fragment coverages (20,30 and 40\%), as detailed in Table 1. Here, the two used rainfall intensities (i.e., 28 and $74 \mathrm{~mm} \mathrm{~h}^{-1}$ ) are realistic rainfall rates for the city of Lausanne (Switzerland) (Baril, 1991). The lower rainfall rate was chosen as slightly exceeding $25 \mathrm{~mm} \mathrm{~h}^{-1}$, the value reported as a threshold for significant erosion in central Europe (Morgen, 2005), while the higher intensity illustrates the maximum rainfall rate expected for Lausanne.

Four sequential experiments, denoted H7-E1, H7-E2, H7-E3, and H7-E4 are taken from Jomaa et al. (2013; 2012b), and experiment H6 from Jomaa et al. (2012b). Experiment H6 used two flumes, H6-F1 (bare soil) and H6-F2 (20\% rock fragment coverage), each subjected to $3 \mathrm{~h}$ precipitation at a rate of $74 \mathrm{~mm} \mathrm{~h}^{-1}$. Experiments involving multiple rainfall events (H7E1, E2, E3 and E4) used $4 \times$ 2-h precipitation rates (28, 74, 74 and $28 \mathrm{~mm} \mathrm{~h}^{-1}$, respectively) with $22 \mathrm{~h}$ of natural air drying between events. These experiments permitted investigation of the effects of progressive raindrop soil compaction on the effluent sediment concentrations of the individual size classes. Again, the two flumes had the same conditions, Flume 1 was bare 
soil and the surface of Flume 2 was covered by $40 \%$ rock fragments. In addition, a

138 (previously unreported) 5-h duration experiment was conducted to capture long-time behaviour using a precipitation rate of $74 \mathrm{~mm} \mathrm{~h}^{-1}$. This is denoted as H8 where H8-F1 used bare soil and H8-F2 had 30\% rock fragment coverage. Experiment H8 was prepared similarly to the other experiments (H6 and H7), except that the topsoil surface was initially compacted dry using a 70-kg roller/compactor. Thus, in total three different initial soil surface conditions were considered:

1. Hand cultivated and smoothed;

2. Undergoing raindrop compaction (through multiple rainfall events); and

3. Hand cultivated and smoothed, then dry-compacted.

Table 1 lists the precipitation rate and duration, the initial soil conditions and moisture content for each experiment. All experiments used a 2.2\% slope, and rainfall detachment was the dominant erosive process based on stream power calculations (Jomaa et al., 2010; 2012a,b).

\subsection{Analyses}

The collected discharge samples were utilized to determine discharge rates and sediment concentrations during the erosive events. For each sample, the total sediment concentration and the sediment concentrations of seven particle-size classes $(<2,2-20,20-50,50-100,100$ 315, 315-1000 and > $1000 \mu \mathrm{m}$ ) were analysed. Concentrations were determined using sieving for three largest size classes (> $100 \mu \mathrm{m})$ and laser diffraction for the rest (Jomaa et al., 2010).

$$
\text { Similarly to Jomaa et al. (2012a), results from experiments conducted using different }
$$
precipitation rates, initial soil conditions and surface rock fragment coverage were analysed to test if the sediment concentrations (in the flume effluent) of the individual size classes decreased proportionally to the area exposed, as was found for the total suspended sediment 
concentrations. The cumulative eroded mass per unit width was computed for each flume and experiment as the sum of multiplying the measured sediment concentration with its corresponding discharge rate per unit width. Then, the eroded mass from the rock fragmentcovered flume was estimated by multiplying the cumulative eroded mass on the bare soil by the fraction of exposed surface area in flume 2. More details of these calculations are given in Jomaa et al. (2012a).

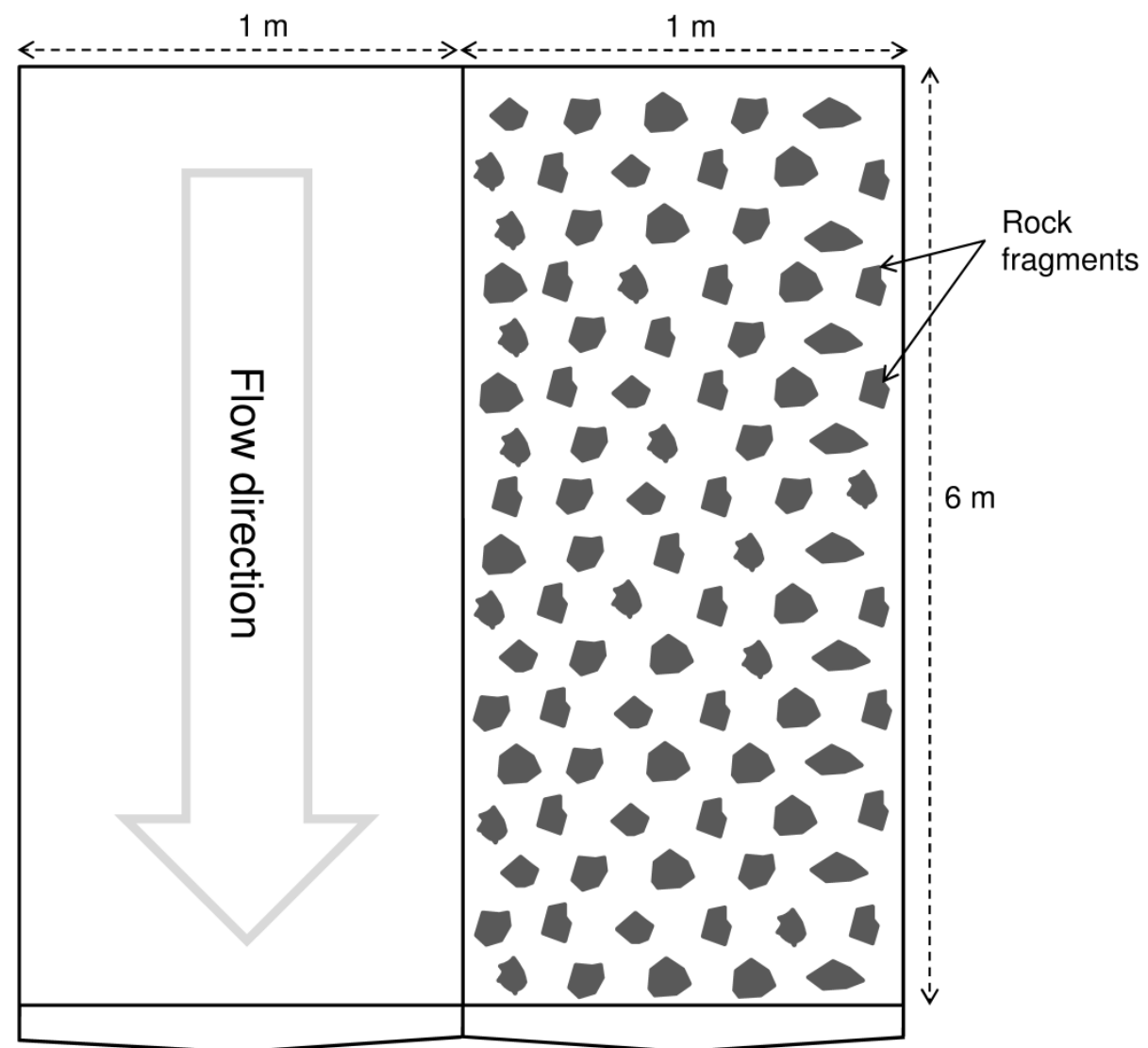

Flume 1

Flume 2

Fig. 1. Design of experiments (figure modified from Jomaa et al., 2012b). The 6-m $\times 2-m$

168 flume was divided into two 6-m $\times 1-\mathrm{m}$ flumes. Note that the flumes are not drawn to scale.

169 For experiments H6, H7- E1-E4, and H8, Flume 1 was bare soil while Flume 2 was covered by surface rock fragments (Table 1). 
Table 1. Summary of the precipitation-driven erosion experiments. All experiments were performed using the same soil in the EPFL erosion flume. Note that it was assumed that steady state was achieved when concentrations in the flume effluent showed negligible change with time relative to the range of concentrations measured. F1 and F2 refer to Flume 1 and Flume 2, respectively. Shaded in grey are four multiple rainfall events. For these, E1-E4 refer to the Event number (i.e., rainfall events applied successively to the same soil). For experiment H8, the topsoil surface was dry hand-cultivated, smoothed, and then compacted uniformly.

\begin{tabular}{|c|c|c|c|c|c|c|c|c|}
\hline \multirow{2}{*}{ Experiment } & \multirow{2}{*}{$\begin{array}{l}\text { Soil surface } \\
\text { condition }\end{array}$} & \multirow{2}{*}{$P^{\mathrm{a}}\left(\mathrm{mm} \mathrm{h}^{-1}\right)$} & \multirow{2}{*}{$\begin{array}{l}\text { Duration } \\
\text { (h) }\end{array}$} & \multicolumn{2}{|c|}{ Moisture content ${ }^{\mathrm{b}}(\%)$} & \multirow{2}{*}{$f^{\mathrm{c}}\left(\mathrm{mm} \mathrm{h}^{-1}\right)$} & \multirow{2}{*}{$t_{r}{ }^{\mathrm{d}}(\min )$} & \multirow{2}{*}{ Initial soil condition } \\
\hline & & & & Initial & Final & & & \\
\hline H6-F1 ${ }^{\mathrm{e}}$ & Bare soil & \multirow{2}{*}{74} & \multirow{2}{*}{3} & 6.8 & 19.1 & 5.30 & 6.07 & \multirow{2}{*}{ Hand-cultivated and smoothed } \\
\hline $\mathrm{H} 6-\mathrm{F} 2{ }^{\mathrm{e}}$ & $20 \%$ cover & & & 6.5 & 21.9 & 19.60 & 8.28 & \\
\hline \multirow{2}{*}{ H7-E1 ${ }^{f}$} & Bare soil & \multirow{2}{*}{28} & \multirow{2}{*}{2} & 7.7 & 18.3 & 7.54 & 14.32 & \multirow{2}{*}{ Hand-cultivated and smoothed } \\
\hline & $40 \%$ cover & & & 8.8 & 30.9 & 13.44 & 27.13 & \\
\hline \multirow{2}{*}{ H7-E2 ${ }^{f}$} & Bare soil & \multirow{2}{*}{74} & \multirow{2}{*}{2} & 19.1 & 22.0 & 2.60 & 1.34 & \multirow{2}{*}{$\begin{array}{l}\text { Compacted and sealed by raindrop splash during H7-E } \\
\text { then left for 22-h air drying }\end{array}$} \\
\hline & $40 \%$ cover & & & 24.8 & 29.5 & 10.16 & 2.06 & \\
\hline \multirow{2}{*}{ H7-E3 ${ }^{f}$} & Bare soil & \multirow{2}{*}{74} & \multirow{2}{*}{2} & 20.4 & 22.0 & 1.96 & 1.23 & \multirow{2}{*}{$\begin{array}{l}\text { Compacted and sealed by raindrop splash during H7-E1 } \\
\text { and H7-E2 then left for 22-h air drying }\end{array}$} \\
\hline & $40 \%$ cover & & & 25.2 & 29.8 & 6.08 & 2.09 & \\
\hline \multirow{2}{*}{$\mathrm{H} 7-\mathrm{E} 4^{\mathrm{f}}$} & Bare soil & \multirow{2}{*}{28} & \multirow{2}{*}{2} & 22.1 & 22.6 & 1.24 & 1.58 & \multirow{2}{*}{$\begin{array}{l}\text { Compacted and sealed by raindrop splash during H7- } \\
\text { E1, H7-E2 and H7-H3 }\end{array}$} \\
\hline & $40 \%$ cover & & & 26.4 & 27.3 & 2.20 & 2.46 & \\
\hline H8-F1 & Bare soil & \multirow{2}{*}{74} & \multirow{2}{*}{5} & 7.3 & 24.5 & 9.80 & 10.67 & \multirow{2}{*}{ Hand-cultivated, smoothed and partially-compacted dry } \\
\hline H8-F2 & $30 \%$ cover & & & 7.0 & 30.1 & 20.48 & 12.62 & \\
\hline
\end{tabular}

${ }^{\text {a }}$ Precipitation rate

${ }^{\mathrm{b}}$ Surface moisture content

${ }^{\mathrm{c}}$ Steady-state infiltration rate ( $f=P-R$, where $R$ is the effective rainfall rate)

${ }^{\mathrm{d}}$ Time-to-runoff

${ }^{\mathrm{e}}$ From Jomaa et al. (2012b)

$181 \quad{ }^{\mathrm{f}}$ From Jomaa et al. (2012b, 2013) 


\section{Results}

Consistent results were obtained for all experiments, so only the typical results (experiments H6 and H7-E2 for flumes 1 and 2) are presented here. The rest of the experimental results for H7-E1, H7-E3, H7-E4 and H8 are given in the Supplementary Material.

Figs 2, 3 and S2-S4 (S refers to Supplementary Material) provide a comparison between measured and predicted size class concentrations as a function of cumulative discharge from the stone-covered flume. Predicted values were obtained by multiplying measured concentrations from the paired bare flume, by the percentage of stone cover. If we first consider steady-state conditions, then all the experimental results presented in Figs 2, 3, and S1-S4 show that the sediment concentrations of the individual size classes are proportional to the area exposed to raindrops. These results also show that this proportionality is independent of initial conditions within the flume and the applied rainfall intensity.

While noting that there are exceptions for some size classes, this proportionality appears to hold also under unsteady conditions, i.e., for the entire erosion event. In particular, Figs 2, S1 and S3, which cover two different initial conditions and rainfall rates (Table 1), show that the scaling relationship does surprisingly well for all times across all size classes. Figs S2 and S4 showed good agreement (lowest $\mathrm{R}^{2}=0.87$ ) between measured and predicted concentrations for the four largest particles, > $50 \mu \mathrm{m}$, with a slight overestimation occurring for the smaller particles at small discharges (or early times). Overall though, the predictions are still quite good. Fig 3 provides mixed results with excellent agreement (lowest $\mathrm{R}^{2}=0.94$ ) obtained for the three smallest sizes, reasonable agreement $\left(R^{2}=0.78\right)$ for the $50-100 \mu m$ range, poor matching for the next two classes (lowest $\mathrm{R}^{2}=0.61$ ) and back to a reasonable match for the largest size class due to its large scatter. Taken together, the results from the six different 

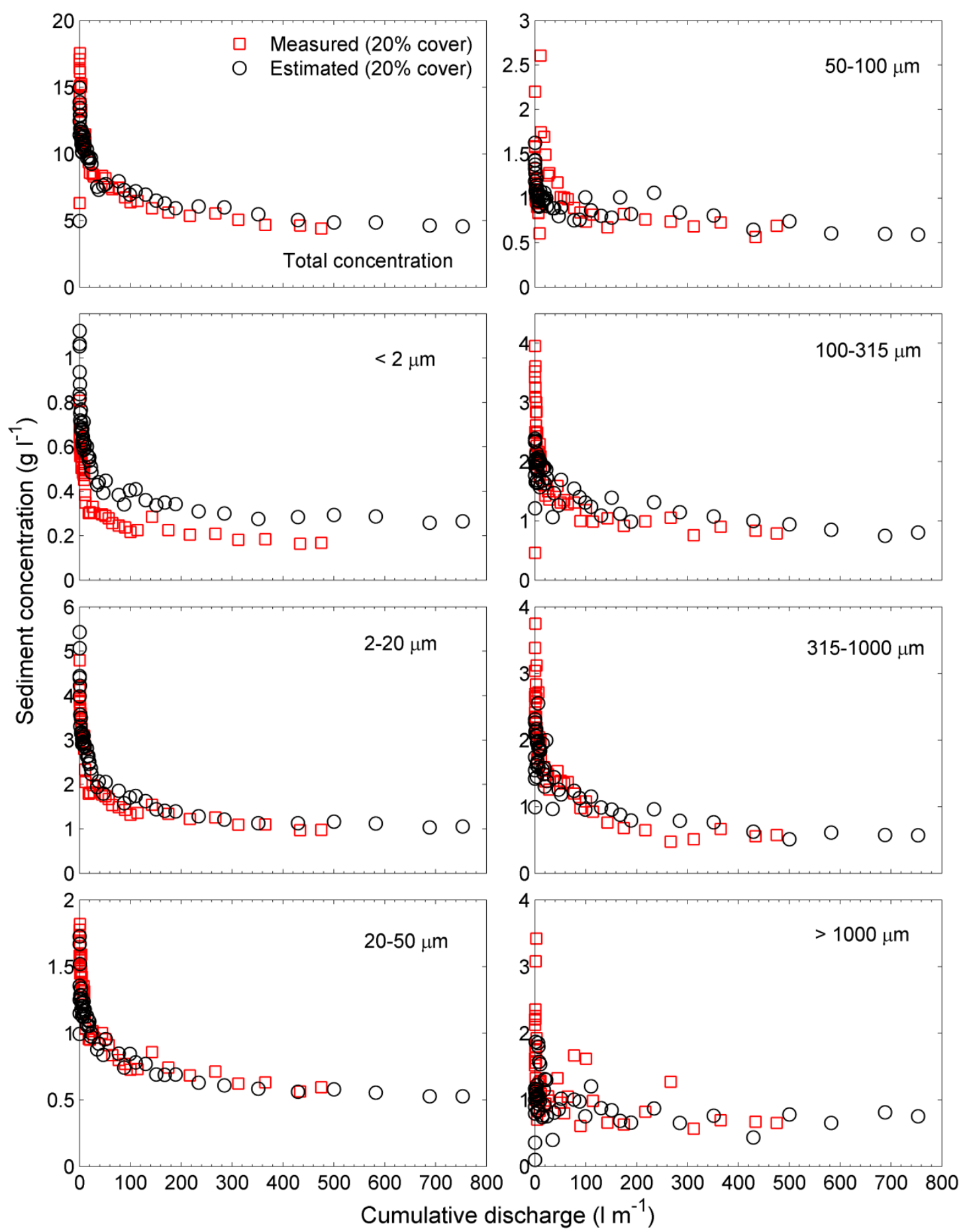

Cumulative discharge $\left(\mathrm{I} \mathrm{m}^{-1}\right)$

Fig. 2. Measured and estimated sediment concentrations as a function of cumulative discharge for experiment H6. The total sediment concentration and concentrations of individual sediment size classes are shown. The estimated sediment concentrations captured well the dynamics of measured data (early peak followed by a rapid decline) for all individual size classes, except the finest class $(<2 \mu \mathrm{m})$ where estimates slightly over-predict the observed concentrations. The estimated sediment concentrations of the medium and larger size classes under-predict the maximum of the early peak, consequently generating an underestimation of the total sediment concentration at the initial erosive stage. At steady state, however, the estimated and measured sediment concentrations are in good agreement. 


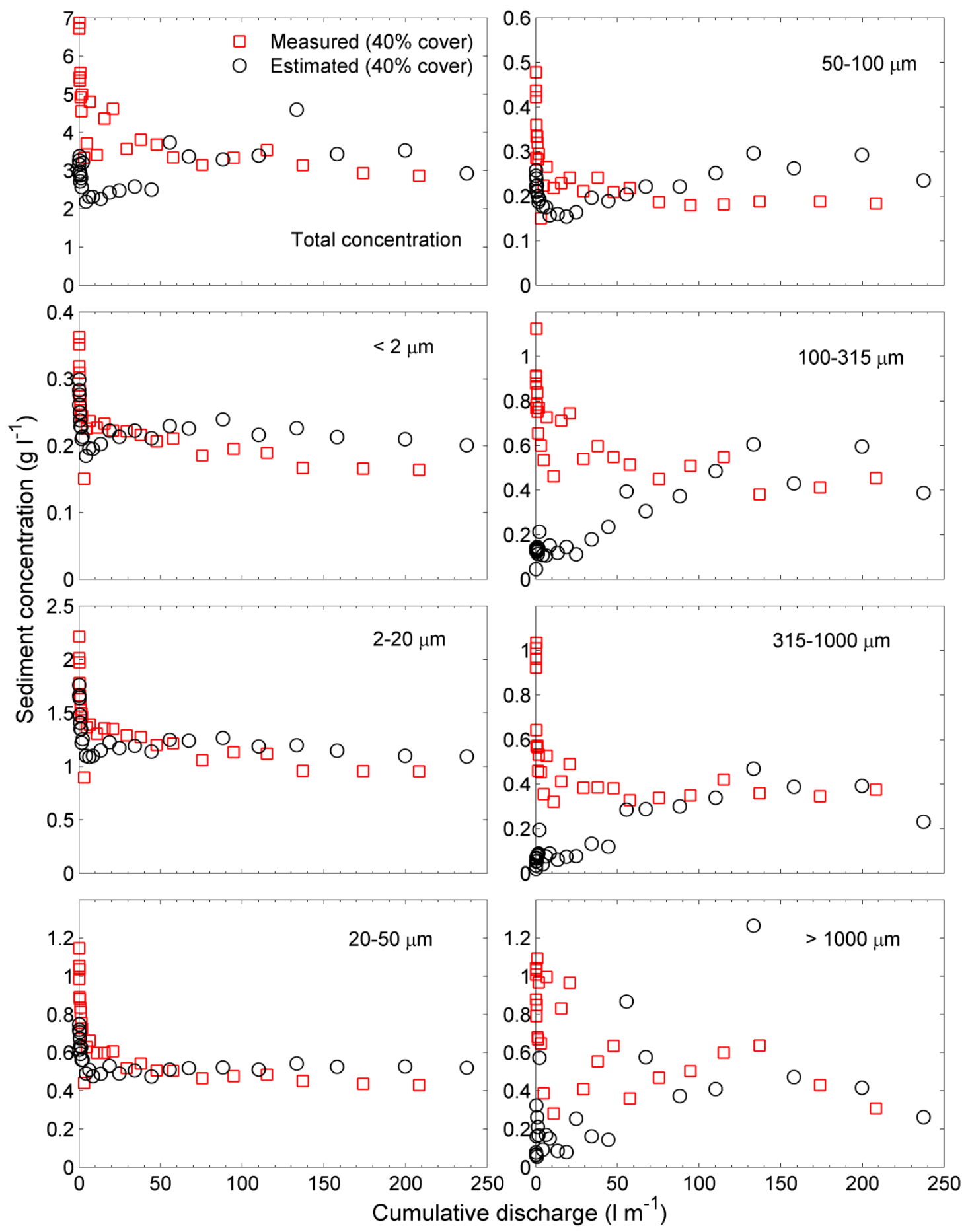

215 Fig. 3. Measured and estimated sediment concentrations as a function of cumulative discharge 216 for experiment H7-E2. The total sediment concentration and concentrations of individual

217 sediment size classes are shown. The estimated sediment concentrations reproduce reasonably 218 well the measured data for the three finest size classes (up to $50 \mu \mathrm{m}$ ) during the entire erosive 219 event, while for the rest of size classes the estimated and measured concentrations are in good 220 agreement only at steady state. Considering the experiment characteristics (Table 1), these 221 results confirm that the short-time behaviour is mainly controlled by the initial and antecedent soil conditions (soil moisture, surface compaction and roughness), in particular for the larger particles. 
experiments suggest that predictions of eroded sediment based on the area exposed to raindrop impact perform remarkably well across a range of different initial conditions and rainfall intensities.

\section{Discussion}

This study completes and provides a fuller picture - in terms of the concentrations of individual size classes - of the results of Jomaa et al. (2012a), who considered only the proportionality between total eroded mass and area exposed. Similarly to the total sediment concentration, the results provide confirmation that, for the considered experiments, sediment concentrations are proportional to the area exposed during the entire erosive event for the individual size classes across a range of initial surface conditions and rainfall rates. In particular, experiments H6, H7-E1, H7-E3 and H7-E4 all show that remarkably good predictions are obtained for all size classes for all times, capturing both the initial rapid rise and subsequent decline in the smaller size classes. For experiment H8, the predictions are still quite good as they again capture the temporal dynamics of the measured data. There is, however, a level of consistent slight over or under estimation of the smaller size classes (< $100 \mu \mathrm{m})$. The only experiment where there appears to be some level of inconsistency between measurement and area-based predictions is for H7-E2. This occurs, however, only for the larger size classes (greater than $100 \mu \mathrm{m}$ ) where the early time behaviours are quite different, but this difference disappears as steady state is approached. For the four particle sizes less than $100 \mu \mathrm{m}$ the predicted concentrations are again extremely good for all times.

\section{Considering the range of different initial conditions and rainfall intensities used in these} experiments, overall the predictions based on exposed area do significantly well. For the few cases where the agreement was slightly poorer this could possibly reflect the effect of nonuniform spatial development of surface roughness and soil sealing due to the antecedent 
conditions. Different factors such as compaction, surface sealing, initial moisture content and surface roughness can control the early stages of soil erosion delivery indirectly through interactions with hydrological features such as the time-to-ponding/runoff, the spatial development of overland flow depth and the infiltration rate. The initial moisture content affects the short time hydrological response through the time-to-ponding and runoff, which in turn influences the overland flow depth development and consequently soil erosion detachment (H6 versus H7-E2 and H7-E3). For example, the times-to-runoff for experiment H7-E1, where the compaction effects were significant (Jomaa et al, 2012b), were 14.3 and 27.1 min for Flumes 1 and 2, respectively (Table 1). However, for the other experiments the time-to-runoff was less than 3 min independent of the precipitation rate (H7- E2-E4).

Jomaa et al. (2012b) reported that the presence of rock fragments on the topsoil affects the surface sealing development and infiltration rate compared with the bare flume (Table 1). Thus, another possible reason of the differences with the predictions for some size classes could be in the different contributions of the individual size classes to surface sealing. When the soil was initially dry, freshly hand-cultivated and disaggregated, the infiltration and soil erosion rates were greater after the commencement of runoff. The time to reach steady-state equilibrium was also delayed compared with experiments that were conducted on initially wet, sealed and compacted soil (H6 versus H7-E2-E3 and H7-E1 versus H7-E4).

Comparing the results obtained from Flumes 1 and 2 through the multiple rainfall events, the data show that the contributions of the larger size classes varied considerably (Table 1 and Fig. 3). For example, for experiment H7-E2, the early peak of sediment concentrations for three largest size classes $(>100 \mu \mathrm{m})$ disappeared for bare soil conditions (Flume 1) compared with the surface-protected flume (Flume 2). This is due to the different antecedent conditions (H7-E1 was followed by $22 \mathrm{~h}$ of air drying) where surface sealing, compaction and roughness 
did not develop similarly for both flumes (Jomaa et al., 2013). The presence of surface rock fragments on Flume 2 increased the water depth due to the reduction of cross-sectional area available for flow, which increased the infiltration rate and reduced detachment of the soil surface (raindrop detachment is attenuated by the increased water depth). Previous experiments consistently found that larger particles are more sensitive to these conditions as their motion is likely due to raindrop splash in addition to suspension within the overland flow (Asadi et al., 2007; Heng et al., 2009; Kinnell, 2009).

In addition, surface rock fragments prevent the development of surface sealing beneath them during the erosion event (Jomaa et al., 2012b; Poesen et al., 1999; Rieke-Zapp et al., 2007). However, between the rock fragments, the surface sealing develops similarly to the bare flume conditions, i.e., soil erosion is controlled by the area exposed and effective precipitation rate (Fig. 3).

Numerous studies have been conducted on the effect of rock fragments on soil erosion and hydrological processes (e.g., Cerdà, 2001; Jiménez et al., 2016; Zhang et al., 2016). In the recent review of Zhang et al. (2016), it was concluded that the effect of rock fragments on soil hydrological processes is inconsistent (positive/negative), and depends on the features of rock fragments (such as coverage, size, position, spatial distribution and morphology) as well as their interaction with soil and weather conditions. Thus, the outcome of this study was likely possible only when replicates of laboratory flume experiments were carried out under carefully controlled conditions and with a consistent feature of rock fragments resting on the flume topsoil surface.

Previously, we modelled experiments H6, H7-E1, H7-E2, H7-E3 and H7-E4 using the Hairsine-Rose model (Hairsine and Rose, 1991; Jomaa et al., 2013; Jomaa et al., 2012b; Rose et al., 1983a,b), where the shielding effect of rock fragment cover was considered. The linear 
scaling model deduced from the area-based predictions presented here was compared with

297 these existing results (plots not shown). In short, the linear scaling and the HR model predictions gave similar results, with neither approach being consistently better.

\section{Conclusions}

These results generalize the previous findings of Jomaa et al. (2012a), viz., that in laboratory flume experiments, soil erosion - in terms of total and individual size classes - is proportional to area exposed throughout the erosive event and that soil erosion can be scaled linearly by the area exposed to raindrop detachment for all size classes. At the initial erosive phase, sediment delivery from the laboratory flume is sensitive to the antecedent soil conditions. It seems that the non-uniform development of surface roughness and soil sealing during the prior erosive event influence the soil erosion delivery. The concentrations of the larger size classes are more affected by the antecedent soil conditions than are the concentrations of the finer particles. At steady state, however, the results suggest that the proportionality between soil erosion delivery (total and individual size classes) and area exposed to raindrops holds independent of the initial soil conditions.

\section{Acknowledgement}

This research was supported by SNF 144320. 
Asadi, H., Ghadiri, H., Rose, C.W., Rouhipour, H., 2007. Interrill soil erosion processes and their interaction on low slopes. Earth Surface Processes and Landforms, 32, 711-724, DOI:10.1002/esp.1426.

Baril, P. (1991), Erodibilité des sols et érodabilité des terres: Application au plateau Vaudois, PhD thesis, Ecole Polytech. Féd. de Lausanne (EPFL), Switzerland, 218 pp., DOI:10.5075/epflthesis-940.

Bryan, R.B., 2000. Soil erodibility and processes of water erosion on hillslope. Geomorphology, 32, 385-415, DOI:10.1016/S0169-555X(99)00105-1.

Butzen, V., Seeger, M., Wirtz, S., Huemann, M., Mueller, C., Casper, M., Ries, J.B., 2014. Quantification of Hortonian overland flow generation and soil erosion in a Central European low mountain range using rainfall experiments. Catena, 113, 202-212, DOI:10.1016/j.catena.2013.07.008.

Cerdà, A., 2001. Effects of rock fragment cover on soil infiltration, interrill runoff and erosion. European Journal of Soil Science, 52, 59-68, DOI: 10.1046/j.1365-2389.2001.00354.x.

Cerdà, A., González-Pelayo, O., Giménez-Morera, A., Jordán, A., Pereira, P., Novara, A., Brevik, E.C., Prosdocimi, M., Mahmoodabadi, M., Keesstra, S., García Orenes, F., Ritsema, C., 2016. The use of barley straw residues to avoid high erosion and runoff rates on persimmon plantations in Eastern Spain under low frequency - high magnitude simulated rainfall events. Soil Research, 54, DOI: 10.1071/SR15092.

de Vente, J., Poesen, J., Verstraeten, G., 2005. The application of semi-quantitative methods and reservoir sedimentation rates for the prediction of basin sediment yield in Spain. Journal of Hydrology, 305, 63-86, DOI:10.1016/j.jhydrol.2004.08.030.

de Vente, J., Poesen, J., Verstraeten, G., Govers, G., Vanmaercke, M., Van Rompaey, A., Arabkhedri, M., Boix-Fayos, C., 2013. Predicting soil erosion and sediment yield at regional scales: Where do we stand? Earth-Science Reviews, 127, 16-29, DOI:10.1016/j.earscirev.2013.08.014.

Hairsine, P.B., Rose, C.W., 1991. Rainfall detachment and deposition: Sediment transport in the absence of flow-driven processes. Soil Science Society of America Journal. 55, 320-324, DOI: 10.2136/sssaj1991.03615995005500020003x.

Haregeweyn, N., Poesen, J., Nyssen, J., Verstraeten, G., de Vente, J., Govers, G., Deckers, S., Moeyersons, J., 2005. Specific sediment yield in Tigray-Northern Ethiopia: Assessment and semi-quantitative modelling. Geomorphology, 69, 315-331, DOI:10.1016/j.geomorph.2005.02.001.

Haregeweyn, N., Yohannes, F., 2003. Testing and evaluation of the agricultural non-point source pollution model (AGNPS) on Augucho catchment, western Hararghe, Ethiopia. Agriculture, Ecosystems and Environment, 99, 201-212, DOI:10.1016/S0167-8809(02)00120-2.

Harmel, R.D., Richardson, C.W., King, K.W., Allen, P.M., 2006. Runoff and soil loss relationships for the Texas Blackland Prairies ecoregion. Journal of Hydrology, 331, 471-483, DOI:10.1016/j.jhydrol.2006.05.033.

Heng, B.C.P., Sander, G.C., Scott, C.F., 2009. Modeling overland flow and soil erosion on nonuniform hillslopes: A finite volume scheme. Water Resources Research, 45, W05423, DOI: 10.1029/2008WR007502.

Iserloh, T., Ries, J.B., Arnaez, J., Boix Fayos, C., Butzen, V., Cerdà, A., Echeverría, M.T., FernándezGálvez, J., Fister, W., Geißler, C., Gómez, J.A., Gómez-Macpherson, H., Kuhn, N.J., Lázaro, R., León, F.J., Martínez-Mena, M., Martínez-Murillo, J.F., Marzen, M., Mingorance, M.D., Ortigosa, L., Peters, P., Regüés, D., Ruiz-Sinoga, J.D., Scholten, T., Seeger, M., Solé-Benet, A., Wengel, R., Wirtz, S., 2013. European small portable rainfall simulators: A comparison of rainfall characteristics. Catena, 110, 100-112, DOI: 10.1016/j.catena.2013.05.013. 
Jetten, V., de Roo, A., Favis-Mortlock, D., 1999. Evaluation of field-scale and catchment-scale soil erosion models. Catena, 37, 521-541, DOI:10.1016/S0341-8162(99)00037-5.

Jiménez, M.N., Fernández-Ondoño, E., Ripoll, M.A., Castro-Rodríguez, J., Huntsinger, L., Navarro, F.B., 2016. Stones and organic mulches improve the Quercus Ilex L. afforestation success under Mediterranean climatic conditions. Land Degradation and Development, 27, 357-365, DOI: $10.1002 / \mathrm{ldr} .2250$.

Jomaa, S., 2012. Process-based precipitation-driven soil erosion modeling: Laboratory flume experiments and analysis with the Hairsine-Rose model. PhD thesis, Ecole Polytech. Féd. Lausanne, Lausanne, Switzerland, 200 pp., DOI:10.5075/epfl-thesis-5340.

Jomaa, S., Barry, D.A., Brovelli, A., Heng, B.C.P., Sander, G.C., Parlange, J.-Y., Rose, C.W., 2012a. Rain splash soil erosion estimation in the presence of rock fragments. Catena, 92, 38-48, DOI:10.1016/j.catena.2011.11.008.

Jomaa, S., Barry, D.A., Brovelli, A., Sander, G.C., Parlange, J.-Y., 2013. Effect of antecedent conditions and rock fragment cover on soil erosion dynamics through multiple rainfall events. Journal of Hydrology, 484, 115-127, DOI:10.1016/j.jhydrol.2013.01.021.

Jomaa, S., Barry, D.A., Brovelli, A., Sander, G.C., Parlange, J.-Y., Heng, B.C.P., Tromp-van Meerveld, H.J., 2010. Effect of raindrop splash and transversal width on soil erosion: Laboratory flume experiments and analysis with the Hairsine-Rose model. Journal of Hydrology, 395, 117-132, DOI:10.1016/j.jhydrol.2010.10.021.

Jomaa, S., Barry, D.A., Heng, B.C.P., Brovelli, A., Sander, G.C., Parlange, J.-Y., 2012b. Influence of rock fragment coverage on soil erosion and hydrological response: Laboratory flume experiments and modeling. Water Resources Research, 48, W05535, DOI: 10.1029/2011WR011255.

Keesstra, S., Pereira, P., Novara, A., Brevik, E.C., Azorin-Molina, C., Parras-Alcantara, L., Jordan, A., Cerda, A., 2016. Effects of soil management techniques on soil water erosion in apricot orchards. Science of the Total Environment, 551, 357-366, DOI:10.1016/j.scitotenv.2016.01.182.

Kim, J., 2013. A holistic approach to multi-scale, coupled modeling of hydrologic processes, flow dynamics, erosion, and sediment transport. PhD thesis, Univ. Mich, Ann Arbor, Michigan, USA, 285pp, https://deepblue.lib.umich.edu/handle/2027.42/98011 (last accessed 11 January 2017).

Kinnell, P.I.A., 2009. The impact of slope length on the discharge of sediment by rain impact induced saltation and suspension. Earth Surface Processes and Landforms, 34, 1393-1407, DOI: 10.1002/esp.1828.

Lassu T., M., Seeger, P., Peters, S.D., Keesstra, 2015. The Wageningen rainfall simulator: Set-up and calibration of an indoor nozzle-type rainfall simulator for soil erosion studies. Land Degradation and Development, 26, 604-612, DOI: 10. 1002/ldr. 2360.

Liu, Q.J., Shi, Z.H., Yu, X.X., Zhang, H.Y., 2014. Influence of microtopography, ridge geometry and rainfall intensity on soil erosion induced by contouring failure. Soil and Tillage Research, 136, 1-8, DOI:10.1016/j.still.2013.09.006.

Martínez-Murillo, J.F., Nadal-Romero, E., Regües, D., Cerdà, A., Poesen, J., 2013. Soil erosion and hydrology of the western Mediterranean badlands throughout rainfall simulation experiments: A review. Catena, 106, 101-112, DOI:10.1016/j.catena.2012.06.001.

Morgan, R.P.C., 2005. Soil Erosion and Conservation. Third edition, Blackwell Science Ltd., Malden, Massachusetts, USA, 304 pp.

Nearing, M.A., Nichols, M.H., Stone, J.J., Renard, K.G., Simanton, J.R., 2007. Sediment yields from unit-source semiarid watersheds at Walnut Gulch. Water Resources Research, 43, W06426, DOI:10.1029/2006WR005692. 
Pierson, F.B., Slaughter, C.W., Cram, Z.K., 2001. Long-term stream discharge and suspendedsediment database, Reynolds Creek experimental watershed, Idaho, United States. Water Resources Research, 37, 2857-2861, DOI: 10.1029/2001WR000420.

Poesen, J., De Luna, E., Franca, A., Nachtergaele, J., Govers, G., 1999. Concentrated flow erosion rates as affected by rock fragment cover and initial soil moisture content. Catena, 36, 315-329, DOI:10.1016/S0341-8162(99)00044-2.

Prosdocimi, M., Jordán, A., Tarolli, P., Keesstra, S., Novara, A., Cerdà, A., 2016. The immediate effectiveness of barley straw mulch in reducing soil erodibility and surface runoff generation in Mediterranean vineyards. Science of the Total Environment, 547, 323-330, DOI:10.1016/j.scitotenv.2015.12.076.

Rieke-Zapp, D., Poesen, J., Nearing, M.A., 2007. Effects of rock fragments incorporated in the soil matrix on concentrated flow hydraulics and erosion. Earth Surface Processes and Landforms, 32, 1063-1076, DOI:10.1002/esp.1469.

Ries, J.B., Marzen, M., Iserloh, T., Fister, W., 2014. Soil erosion in Mediterranean landscapes Experimental investigation on crusted surfaces by means of the Portable Wind and Rainfall Simulator. Journal of Arid Environments, 100-101, 42-51, DOI:10.1016/j.jaridenv.2013.10.006.

Rose, C.W., Williams, J.R., Sander, G.C., Barry, D.A., 1983a. A mathematical model of soil erosion and deposition processes: I. Theory for a plane land element. Soil Science Society of America Journal, 47, 991-995, DOI:10.2136/sssaj1983.03615995004700050030x.

Rose, C.W., Williams, J.R., Sander, G.C., Barry, D.A., 1983b. A mathematical model of soil erosion and deposition processes: II. Application to data from an arid-zone catchment. Soil Science Society of America Journal, 47, 996-1000, DOI:10.2136/sssaj1983.03615995004700050031x.

Saedi, T., Shorafa, M., Gorji, M., Moghadam, B.K., 2016. Indirect and direct effects of soil properties on soil splash erosion rate in calcareous soils of the central Zagross, Iran: A laboratory study. Geoderma, 271, 1-9, DOI: 10.1016/j.geoderma.2016.02.008.

Tromp-van Meerveld, H.J., Parlange, J.-Y., Barry, D.A., Tromp, M.F., Sander, G.C., Walter, M.T., Parlange, M.B., 2008. Influence of sediment settling velocity on mechanistic soil erosion modeling. Water Resources Research, 44, W06401, DOI: 10.1029/2007WR006361.

Zhang, Y., Zhang, M., Niu, J., Li, H., Xiao, R., Zheng, H., Bech, J., 2016. Rock fragments and soil hydrological processes: Significance and progress, Catena, 147, 153-166, DOI.org/10.1016/j.catena.2016.07.012. 
2 Linear scaling of precipitation-driven soil erosion in laboratory flumes

3 S. Jomaa ${ }^{\text {a,* }}$, D.A. Barry ${ }^{\text {b }}$, M. Rode ${ }^{\text {a }}$, G.C. Sander ${ }^{\text {c }}$, J.-Y. Parlange ${ }^{\text {d }}$

$4 \quad{ }^{\mathrm{a}}$ Department of Aquatic Ecosystem Analysis and Management, Helmholtz Centre for

5 Environmental Research - UFZ, Brueckstrasse 3a, 39114 Magdeburg, Germany. Ph. +49

6 (391) 810-9135; +49 (391) 810-9650; Fax. +49 (391) 810-9111. E-mail addresses:

7 seifeddine.jomaa@ufz.de, michael.rode@ufz.de

8 b Laboratoire de technologie écologique (ECOL), Institut d'ingénierie de l'environnement

9 (IIE), Faculté de l'environnement naturel, architectural et construit (ENAC), Station 2, Ecole

10 Polytechnique Fédérale de Lausanne (EPFL), 1015 Lausanne, Switzerland. Ph. +41 (21) 693-

11 5576; Fax.+41 (21) 693-8035. E-mail address: andrew.barry@epfl.ch

$12{ }^{\mathrm{c}}$ Department of Civil and Building Engineering, Loughborough University, Loughborough

13 LE11 3TU United Kingdom. Tel. +44 (1509) 223-777; Fax. +44 (1509) 223-981. E-mail

14 address: g.sander@lboro.ac.uk

15 d Department of Biological and Environmental Engineering, Cornell University, Ithaca, New

16 York 14853-5701 USA. Ph. +1 (607) 255-2476; Fax. +1 (607) 255-4080. E-mail address:

17 jp58@cornell.edu 
Details of the distributions of particle sizes classes in the flume effluent of experiments H7-

19 E1, H7-E3, H7-E4 and H8 are given here. Results obtained for these experiments are consistent with findings obtained for experiments H6 and H7-E2. Thus, even though these experiments were conducted with different rock fragment coverages, rainfall intensities and initial soil surface conditions, the estimated sediment concentrations taking the area-based approach into account reproduced satisfactorily the measured sediment concentration at 24 steady state, as can be seen in Figs. S1-S4. 


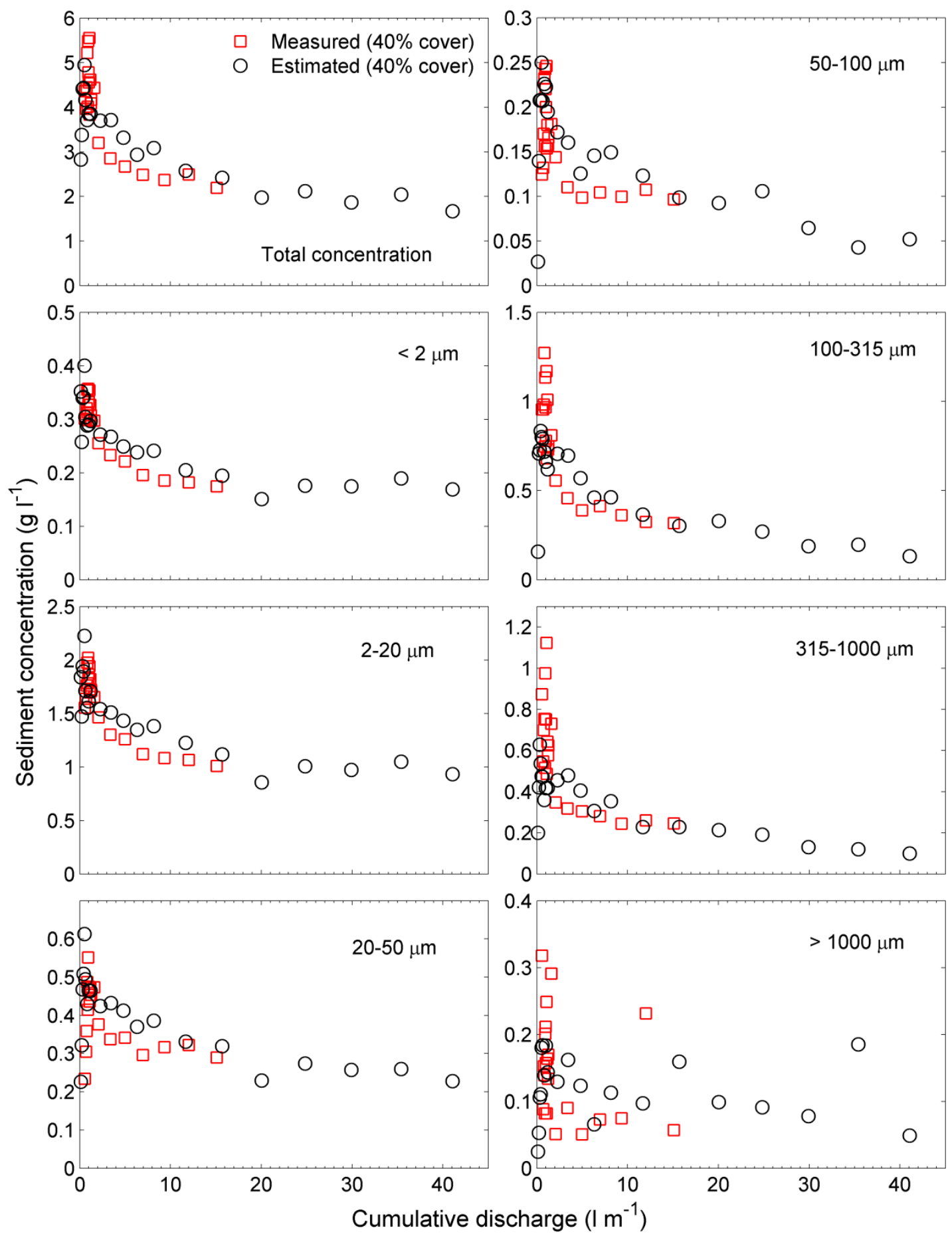

Fig. S1. The estimated and measured sediment concentrations collected from experiment H7E1. Consistent with experiment H6, the estimated total and individual size classes reproduce well the measured data during the entire erosion event. 


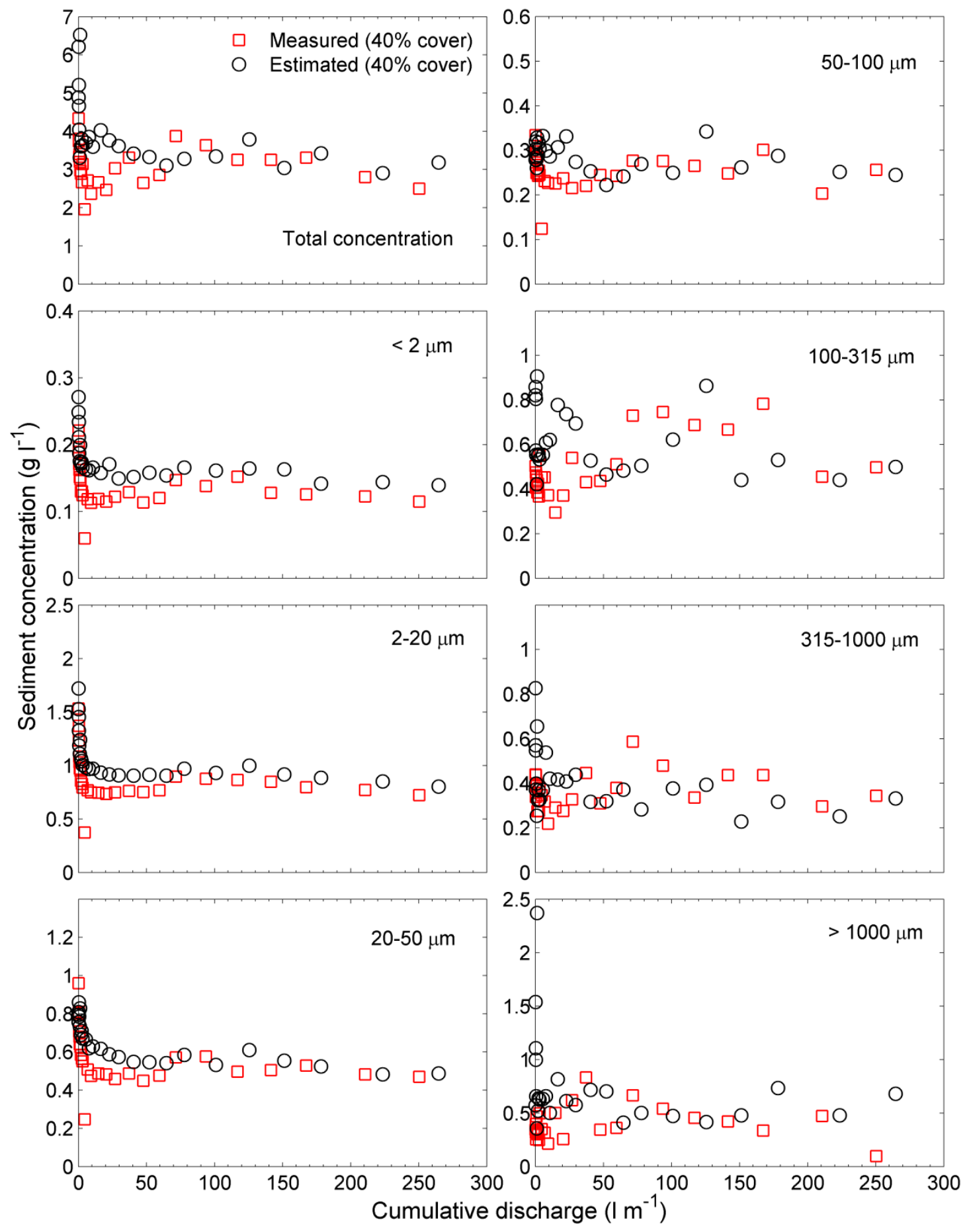

Fig. S2. The measured and estimated sediment concentrations of the individual size classes of experiment H7-E3. The plots show that discrepancies between estimates and observations occur during the initial phase of the erosive event. 


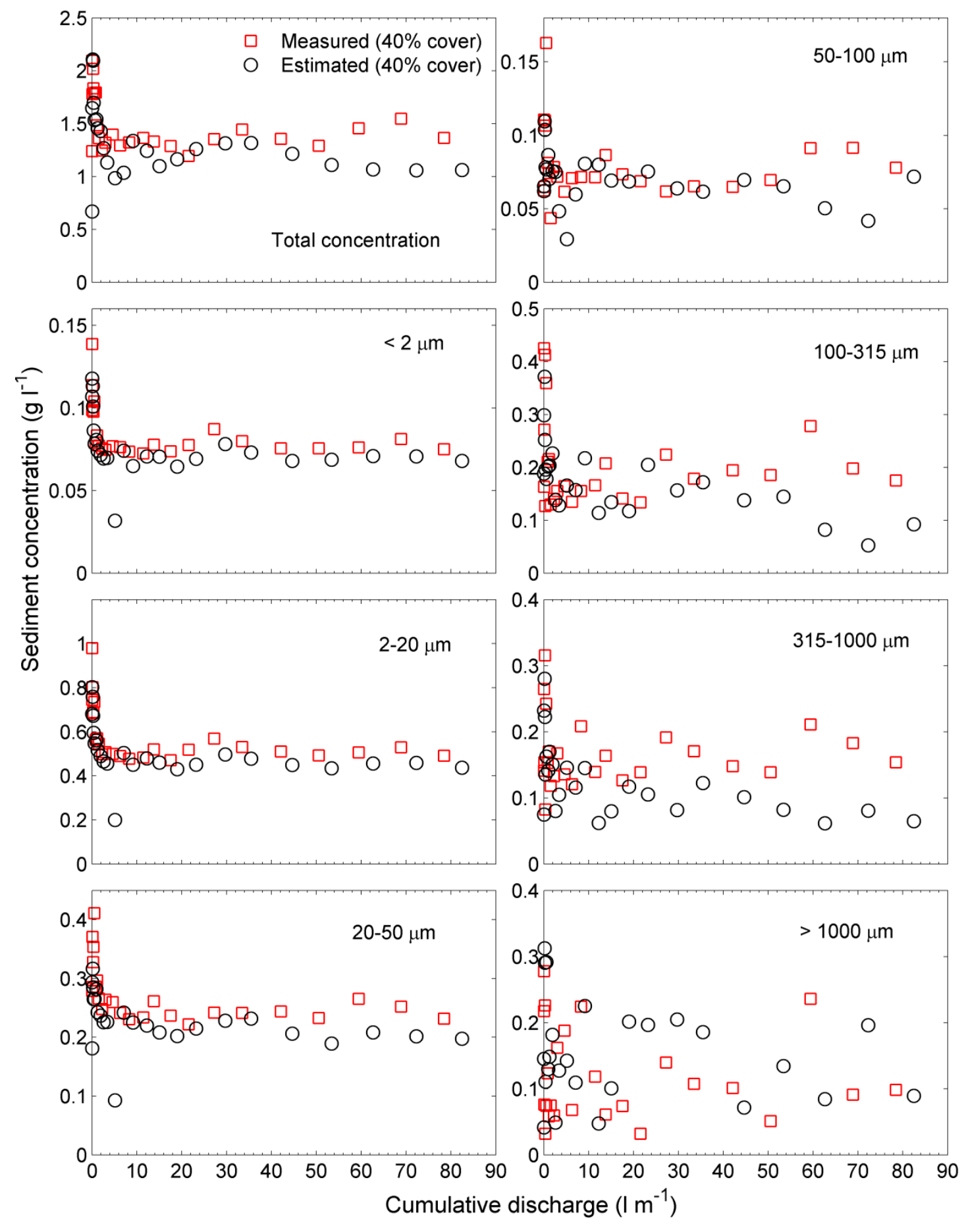

Fig. S3. Estimated and measured sediment concentrations for total and individual size classes

32 for experiment H7-E4. The soil erosion is proportional to the area exposed for a given

33 effective rainfall. Note that the eroded masses (total and individual size classes) are smaller

34 than the previous experiments due to the low precipitation $\left(28 \mathrm{~mm} \mathrm{~h}^{-1}\right)$ and initial soil conditions (compacted and sealed). 

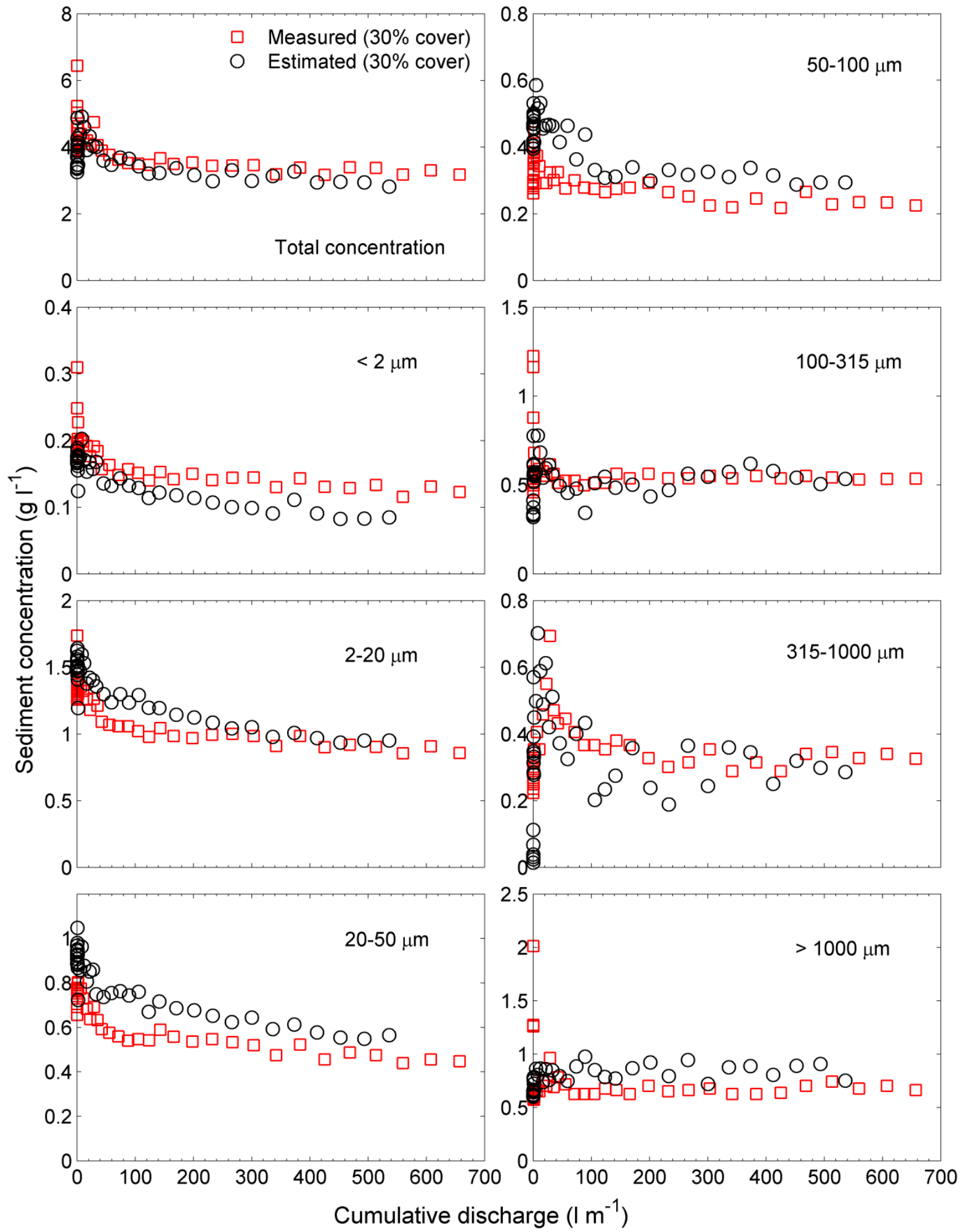

Fig. S4. Estimated and measured sediment concentrations for total and individual size classes obtained during experiment H8. Even for this lengthy experiment (5 h), the individual size classes' sediment concentrations suggest that the true steady state has not been fully reached. 